\title{
Ice Spirals off Barrow as Seen by Satellite
}

\author{
HAROLD SOLOMON ${ }^{1}$ and KRISTINA AHLNÄS ${ }^{2}$
}

\begin{abstract}
RÉSUMÉ. Motoki puis Solomon et Ahlnäs ont signalé l'existance de'figures ressemblant à de grands tourbillons, au droit du courant du Kamchatka, en Septembre et Mars-Avril. Dans ce dernier cas, alors que la limite de banquise se situe plus au sud que la latitude de ces spirales, la glace se prèsente en surface ègalement en spirale.

Le satelite NOAA 5 avait fait pareille observation près de Barrow à la limite des mers de Chukchi et Beaufort, les 29 à 31 Aout 76. L'image radar montre deux spirales de glace, causées par un courant complexe au large de Barrow, de 30 à $50 \mathrm{kms}$ soit environ la moitié de celles du Kamchatka. Les spirales sont une manifestation de courants superficiels de l'eau, dans la zone de glace brisée.

Ces spirales paraissent s'en rouler dans le sens de aiguilles d'une montre comme c'est le cas pour les tourbillons de glace à la fin de l'hiver et pour ceux d'eau libre observés au large du Kamchatka. M. Koshlyakov a noté que plusieurs de ces tourbillons observés lors de l'étude Polymode dans l'ocean Atlantique Nord, montraient des renversements de leur structure thermique, pas bien loin de la surface de l'eau.

La circulation générale en mer de Beaufort se fait suivant un sens giratoire, dảns le sens des aiguilles d'une montre, à grand rayon de courbure mais il est sur qu'au moins en été, l'écoulement littoral se fait vers l'est. En deux jours, la derive atteint $64 \mathrm{kms}$ et 51 $\mathrm{kms}$ plus à l'ouest, soit une vitesse de 1.3 et $1.1 \mathrm{~km} / \mathrm{heure}$.

Les spirales de la mer de Chukchi et du Kamchatka se sont formées de part et d'autre des courant de surface.

Traduit par Alain de Vendigies, Aquitaine Company of Canada Ltd., Calgary.
\end{abstract}

The existence of large eddy-like features in the Kamchatka Current was reported by Motoki (1977) and by Solomon and Ahlnäs (1978). These spirals have been observed in September and in March-April. In the latter case, when pack ice extends south to the latitude of the spirals, ice collects on the surface in a spiral shape.

A similar feature was observed off the const near Barrow at the boundary of the Chukchi and Beaufort Seas by the NOAA-5 satellite on August 29 (Fig. 1), 30 and 31, 1976 (Fig. 2). During the same time period NASA, NOAA, Navy and U.S. Coast Guard, (Gedney et al., 1977) demonstrated an all-weather ice information system for Arctic coastal shipping. The radar image collected on August 30, 1976 shows two ice spirals caused by the complex current pattern off Barrow. On the corresponding NOAA-5 satellite image, the spirals are only partly discernible due to coastal fog. The diameter of the larger and better developed spiral to the north was about $30 \mathrm{~km}$ on August 29 and about $50 \mathrm{~km}$ two days later with the shoreward edge lying about $30 \mathrm{~km}$ off Barrow. Thus, it is about half as large as the Kamchatka spirals. A smaller eddy-like feature appears slightly to the southwest of the larger spiral. These spirals are a manifestation of the surface currents in the water in the broken ice zone

\footnotetext{
'Institute of Marine Science and Technology, Tokai University, Shimizu, Japan

${ }^{2}$ Institute of Marine Science, University of Alaska, Fairbanks, Alaska 99701

Contribution No. 5 of the Pacific International Research Association.
} 


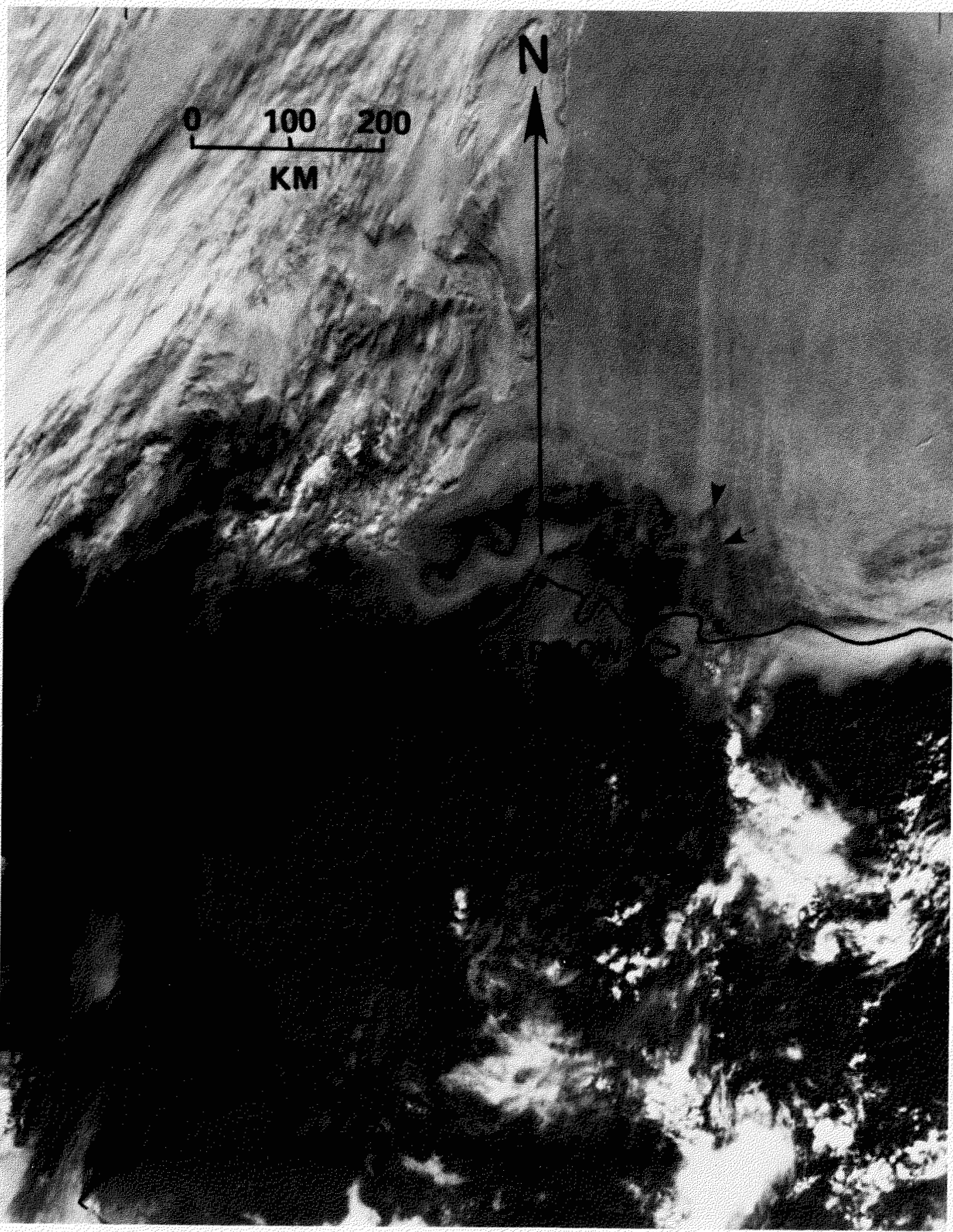

FIG. 1. NOAA-5 satellite image in the visible range on August 29,1976 showing ice spirals NW of Barrow. Arrows indicate reference points for measuring the movement of the ice edge (slightly obscured by thin clouds). Barrow and the coast to the east are covered by low clouds. 


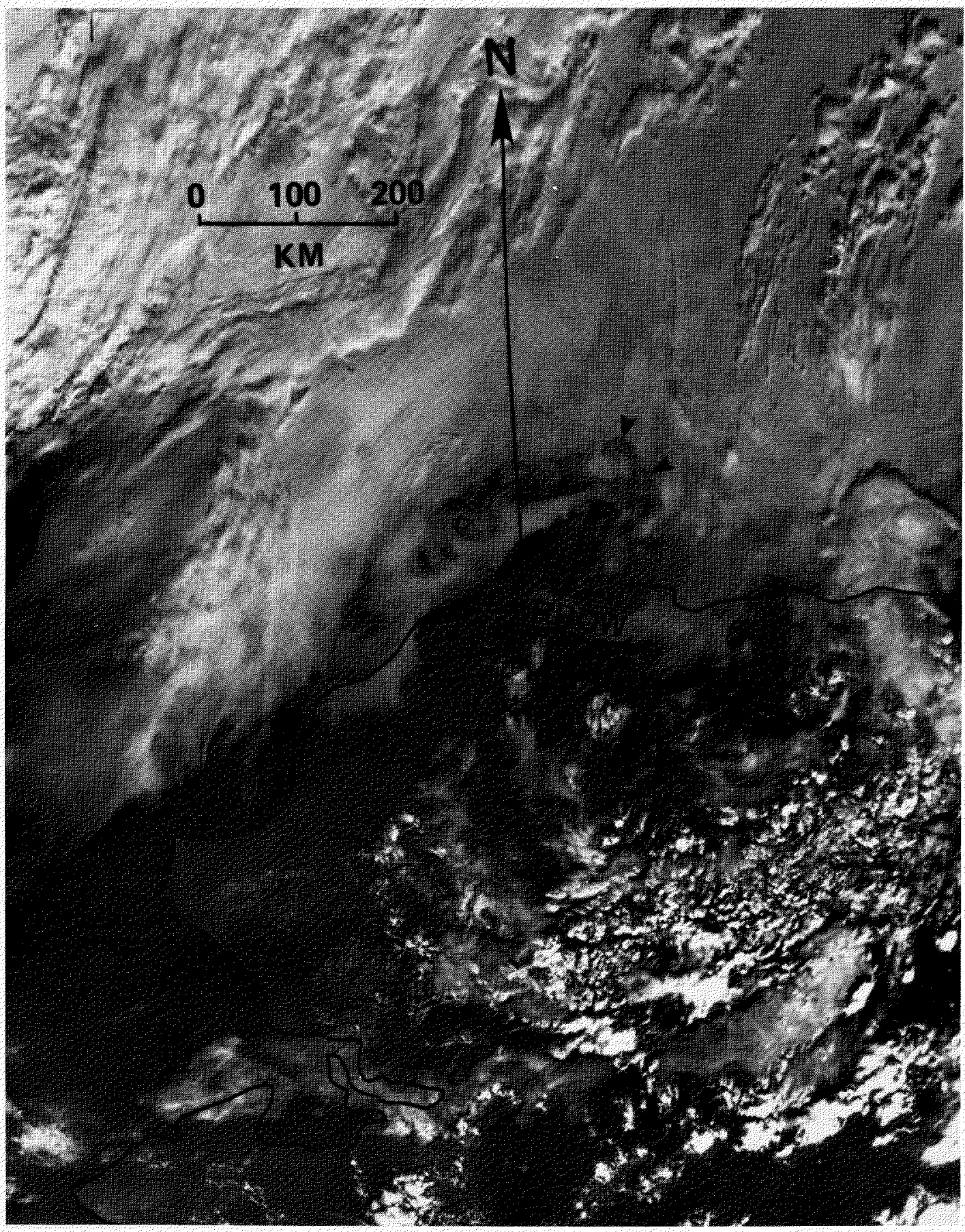

FIG. 2. NOAA-5 satellite image in the visible range on August 31, 1974 showing some growth in the ice spiral NW of Barrow. Some clouds prevail SW of the spiral. Location of arrows as in Figure 1. 
between the coast and the pack-ice edge about $100 \mathrm{~km}$ north of Barrow. One smaller (diameter about $13 \mathrm{~km}$ ) anticyclonically wound spiral can be seen on the corresponding infrared image for August 29 along the southern part of the broken ice edge in Chukchi Sea. However, only a faint wave-like shape is detectable in Figure 1, which is the visible image.

These spirals, or eddies, appear to be rotating clockwise (anticyclonically). This agrees with the sense of the rotation of the ice eddies (in late winter) and open water eddies (in fall) seen off Kamchatka in the western Bering Sea by Solomon and Ahlnäs (1978). The open water eddies (which we assume to be similar in oceanographic structure to the ice eddies) were cold core, which appears to be paradoxical if these eddies are in geostrophic equilibrium. A technical discussion of the difficulties of explaining eddy-like motion can be seen in the Polymode News article by Ahlnäs and Solomon (1979). Burkov and Federov (1979 have noted that some of the eddies observed by the Polymode project in the North Atlantic Ocean, in which extensive subsurface observations were taken, showed reversals of their thermal structure at some depth not far below the sea surface. The deeper part of the eddy had isopycnal (constant density) surfaces convex downward, tending to produce anticyclonic rotation, while the shallower part had isopycnal surfaces convex upward, tending to produce cyclonic rotation. Thus, the surface temperature expression was cold, while the sense of rotation still reflected the dominant deep structure, though the clockwise rotation at the surface was weaker than at the depth where the reversal took place. The cause of this structure remains a mystery.

The overall circulation in the Beaufort Sea usually consists of a large clockwise gyre, but there is evidence that at least in summer the coastal flow is to the east (Hufford, 1973; Paquette and Bourke, 1974). South of Barrow the coastal flow is towards the north. In the vicinity off Point Barrow this northward moving current encounters the Beaufort Sea Gyre. The ice spirals observed might be the combined result of this encounter and the irregular bathymetry around the Barrow Submarine Canyon.

We estimated the movement of the ice edge by projecting a meridian through Barrow and measuring the perpendicular distance to the top and base of another spiral-like feature east of Barrow indicated by arrows in the figures. These locations on the ice edge can be identified on the imagery, although the shape has changed somewhat from August 29 to 31. In the 48-hour period between the satellite orbits the locations of the points indicated had drifted a total of $64 \mathrm{~km}$ and $51 \mathrm{~km}$ respectively to the west. This gives a speed of $1.3 \mathrm{~km} / \mathrm{h}$ and $1.1 \mathrm{~km} / \mathrm{h}$ respectively. The lower drift velocity of the point just at the ice edge might be caused by interference from the eastward flowing coastal current. Averaging the values gives a westward drift of the ice edge of $1.2 \mathrm{~km} / \mathrm{h}$.

It is interesting to speculate on the possibility that sidewall friction at a protruding point such as Point Barrow may produce spirals in the water offshore. Sidewall friction could act on a northward or eastward current to produce clockwise spirals. However, this coastal current appears to be quite 
narrow, and its strength and persistence at Point Barrow have not been established. The more persistent Beaufort Gyre flow is in the opposite direction off Barrow. The late summer timing is probably optimum for consistency with any possible theory (such as sidewall friction or baroclinic instability) which might be advanced to link the spirals to the Alaskan Coastal Current.

\section{ACKNOWLEDGEMENTS}

This study was in part supported under contract 03-5-022-56 between the University of Alaska and NOAA, Department of Commerce through the Outer Continental Shelf Environmental Assessment Program to which funds were provided by the Bureau of Land Management, Department of the Interior; and in part by NSF Grant OCE 77-07804 from the Oceanography Section. We thank Dr. M. Koshlyakov for pointing out the relevance of the observation by Burkov and Federov. Dr. T. Royer and Dr. G. Wendler reviewed the manuscript.

\section{REFERENCES}

AHLNÄS, K. and SOLOMON, H. 1979. Eddy-like features in the Kamchatka Current (unpublished manuscript). Polymode News 60(3): 5-7.

BURKOV, V.A. and FEDEROV, KN. 1979. An anticyclonic eddy in the Sargasso Sea (unpublished manuscript). Polymode News 68.

GEDNEY, R. T., JIRBER, R. J., SCHERTLER, R. J., MUELlER, R. A., CHASE, T. L., KRAMARCHUK, I., NAGY, L. A., HANLON, R. A. and MARK, H. 1977. All-weather ice information system for Alaskan Arctic coastal shipping. Offshore Technology Conference 3003, Houston, Texas, May 1977.

HUFFORD, G. L. 1973. Warm water advection in the southern Beaufort Sea. August-September 1971. Journal of Geophysical Research 78:2702-2707.

MOTOKI, T. 1977. Kamchatka Hanto togan ni hassei shita kaijo no uzu (Eddies on the sea surface occurring off the east coast of the Kamchatka Peninsula). Tenki 24: 605-606.

PAQUETTE, R. G. and BOURKE, R. H. 1974. Observations on the coastal current of Arctic Alaska. Journal of Marine Research 32: 195-207.

SOLOMON, H. and AHLNÄS, K. 1978. Eddies in the Kamchatka Current. Deep-Sea Research, 25: 403-410. 